\title{
Demand for mini cars and large cars, Decay Effects, and Gasoline Demand in Japan.
}

David Bonilla and Klaus E. Schmitz*, Atsushi Akisawa**

Transport Studies Unit, School of Geography and Environment, and Oxford Martin School Oxford University, Oxford OXI 3QY.

Senior Research Fellow.Corresponding author: Email: david.bonilla@ouce.ox.ac.uk.Tel 01865285545

*Research fellow, Harvard Medical School, Childrens Hospital- Genetics, Harvard University, Boston MA, Enders 626, 300 Longwood Avenue. Boston MA. 02115

** Professor; Bio-Applications and Systems Engineering Department, Tokyo University of Agriculture and Technology, 2-24-16 Naka-machi Koganei-shi, Tokyo 184-8588, Japan

Car sales, vehicle choice, gasoline demand models, large cars

\section{Abstract}

Explaining a) why consumers underinvest in new car fuel economy by opting to buy large vehicles, b) why macro shifts in vehicle classes have occurred in the last decades and how c) the effects of vehicle fuel economy and shifts in vehicle mix influence the growth path of gasoline demand is key to design effective energy efficiency goals for transport. As of 2008, 1.9 EXJ (Exajoules) of energy are consumed in Japan by private vehicles producing 124 $\mathrm{MtCO}_{2}$ emissions. For the period 1980 to 2008, we estimate (1) gasoline demand for three vehicle sizes, (2) vehicle sales (3) new car fuel economy changes (the 'real' technical change), and (4) vehicle stocks. Using a data sample for 1980-2008 we find that a) in the short run consumers buy fuel economy, that is sales of mini and small cars increase, but fail to do so in the long run and (b) consumers are increasingly trading in their cars for larger cars . A further finding is that gasoline demand is projected to increase to 2.3 Exajoules by 2035 even with strong penetration of mini cars. The policy implication is clear: Japan's policy to reduce oil dependency to $80 \%$ by 2030 is in peril so long as buyers prefer larger cars and drive ever longer distances. 


\section{Introduction}

In 2008, 54 million Japanese cars (passenger and light two-wheeled vehicles) were driven around 523 billion vehicle-km (VKM) on Japanese roads (Ministry of Land Infrastructure and Transport, 2008) (Table 1). To power this volume of private cars in that year 1.9 EJ (Exajoules) of motor fuels (gasoline) are needed in Japan. A disaggregated model of gasoline demand and car sales is built using data on vehicle age and class (mini, small and standard) for Japan's privately owned car fleet. The model explains the future growth trajectory of gasoline demand and of new car fleet fuel economy . Fuel economy is defined as the increase in the ratio of KM-driven per litre of gasoline consumed of new passenger vehicles). Figure 1 evidences the rapid growth in gasoline consumption until 2002, but consumption falls in 2003-2008.

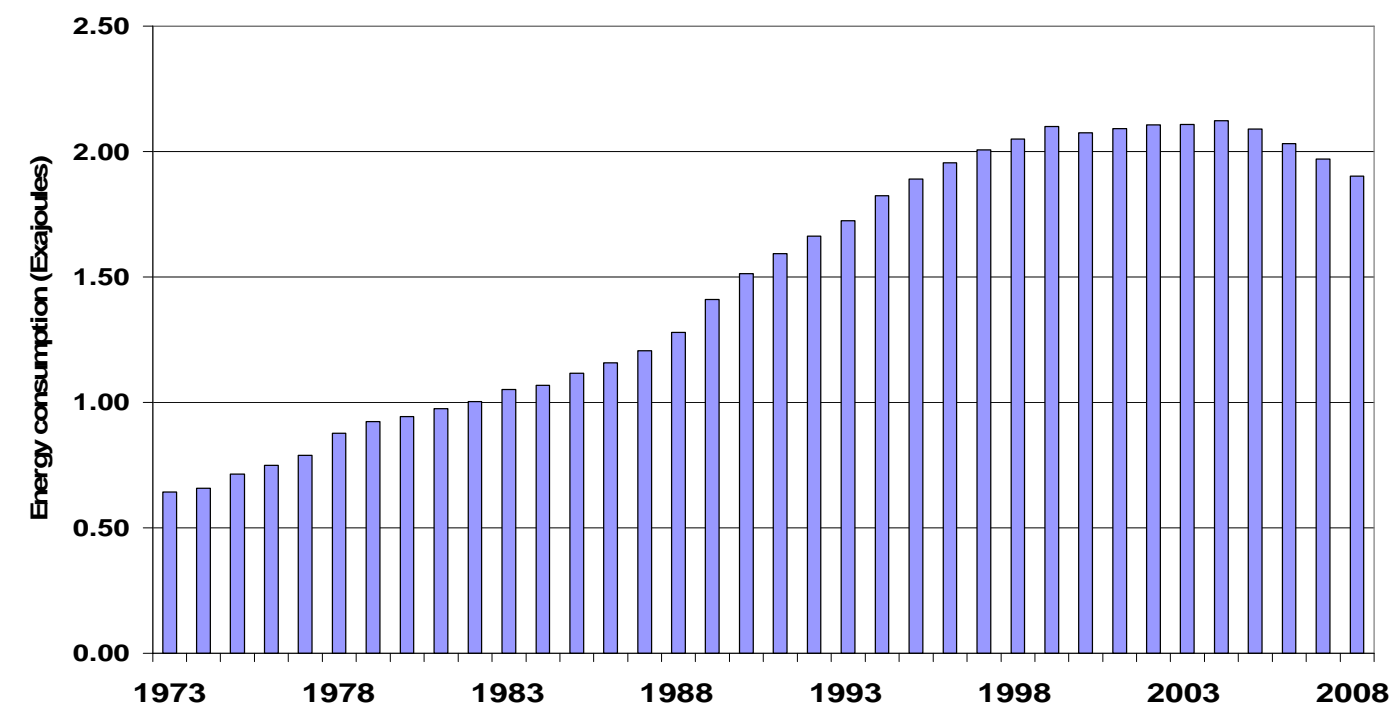

Figure 1. Fuel consumption: passenger cars. Source: author using data of IEEJ (2010) and MLIT 2008)

We have three objectives: the first one is to estimate how changes in market shares of efficient vehicles produce a given level of fuel economy (all Japanese vehicles) and the second one is to estimate how fuel economy (of new cars) influences gasoline demand forecasts by 2035 . The third one is to estimate vehicle stocks. Vehicle stock models complement effectively gasoline 
demand models since the former can explain how old and less, or more, efficient cars are replaced by new ones. In the period of 1973-2008 the small car class has lost considerable market share as consumers have increasingly preferred to buy large cars.

There are three key policy drivers that aim to reduce gasoline demand in Japan. The first is the Kyoto protocol targets, the second is the National Energy Strategy, and the third is the "Top Runner Programme (IEA, 2008). The most effective plan so far is the latter policy instrument. However since most of the $\mathrm{CO}_{2}$ emissions are generated by technology choices that are long lived it is unlikely that Japan will mitigate enough carbon or meet its long term target $80 \%$ for oil dependency by 2030 for the transport sector. In addition, Japan is party to the Kyoto Agreement and so it is required to reduce emissions by $6 \%$ by $2008-2012$ period with 1990 as the base year. As part of the Kyoto protocol target programme the country is aiming to reduce emissions of passenger vehicles by $21 \mathrm{MT}-\mathrm{CO}_{2}$ by 2035 . It should be noted that the Kyoto commitment refers to the six gases and not only to $\mathrm{CO}_{2}$ emissions, as we do, and the commitments end in the 200812 period for the entire economy, however transport is the only sector whose emissions continue to grow for the most part of the last 30 years.

Strikingly, gasoline demand (exajoules or EXJ); using IEEJ (2010) has continued to increase (Figure 1), in most years since 1973 even in the 1990's, which was a period of stagnant growth in Japanese household incomes and of widespread contraction in Japanese economic activity. In 2000-08, gasoline demand has also been stimulated by (a) growth in KM-driven of private cars and (b) lower fuel prices (Table 1) and by the larger stock of large cars, and by relative recovery in the Japanese economy.

The increase in VKM driven during the 1973-2008 of passenger cars sector has tripled the $\mathrm{CO}_{2}$ emissions level in the same period despite improvements in new car fuel economy in the same period (Table 1). The contribution of the passenger sector to overall transport $\mathrm{CO}_{2}$ emissions continues to be large in the same period and that contribution has not declined. Total transport $\mathrm{CO}_{2}$ emissions have 
stabilised in recently but its absolute level remains high. Table 1 reflects the fact that overall energy use of passenger transport is heavily dominated by fossil fuels.

Table 1. Petroleum product demand (EXJ) in Japan: 1990-2008 (Source: MILT, IEA; IEEJ(2010) ${ }^{1}$

\begin{tabular}{|c|c|c|c|c|c|}
\hline & 1973 & 1980 & 1990 & 2005 & 2008 \\
\hline $\begin{array}{l}\% \text { Share of road transport of } \\
\text { final energy use (all transport) }\end{array}$ & 35 & 41 & 49 & 54 & 53 \\
\hline KM/L (all new cars) & 11.4 & 12.8 & 12.4 & 14.1 & 16.1 \\
\hline Vehicle-KM-driven (billion) & 190 & 257 & 366 & 526 & 523 \\
\hline $\begin{array}{l}\text { On road fuel economy } \\
\text { (KM/Litre: All fuels) }\end{array}$ & 10.41 & 9.57 & 8.49 & 7.16 & 8.57 \\
\hline $\begin{array}{c}\text { Final energy consumption } \\
\text { passenger cars (gasoline, } \\
\text { diesel, LPG, electricity) (EXJ) }\end{array}$ & 0.64 & 0.94 & 1.51 & 2.08 & 1.9 \\
\hline $\begin{array}{l}\text { Energy consumption (all } \\
\text { transport)(EXJ) }\end{array}$ & 1.82 & 2.30 & 3.11 & 3.85 & 3.52 \\
\hline Fuel price (Consumer Price & & & & & \\
\hline $\begin{array}{l}\text { Index) US-Cents/Litre } \\
\text { gasoline, } 2005=100)\end{array}$ & 56.2 & 105.2 & 103.1 & 102.5 & 116.7 \\
\hline $\begin{array}{l}\mathrm{CO}_{2} \text { emissions (in million } \\
\text { tonnes) of passenger cars } \\
\text { electricity, gasoline diesel and } \\
\text { others }\end{array}$ & 42 & 61 & 99 & 136 & 124 \\
\hline $\begin{array}{l}\mathrm{CO}_{2} \text { emissions (in million } \\
\text { tonnes) transport sector }\end{array}$ & 119 & 150 & 203 & 252 & 230 \\
\hline
\end{tabular}

For example, in the 1980s gasoline prices remained stable (after a large increase in the previous decade of $49 \%$ ) (in real terms), while in the 90 s a further $20 \%$ decline was recorded (Consumer Price Index in Japanese Yen terms). In 2000-08 a price recovery of 30\% occurs but gasoline

\footnotetext{
${ }^{1} 4.1868\left(\mathrm{X}_{10}{ }^{4}\right)$ Megajoules equals one Tonne of oil equivalent (TOE); one EXJ equals $10^{18}$ joules.
} 
demand was largely insensitive and so were vehicle sales. In 20081.9 EXJ are consumed by private cars compared to nearly 1.12 EXJ in 1985 and $0.64 \mathrm{EJ}$ in 1973.

In 2008, on-road vehicle fuel economy of Japanese private vehicles stands at 8.57 (KM/litre or 11.01 litres/100KM; MLIT, 2008) (using data on gasoline, diesel and LPG, electricity) which is only slightly above its 1990 level $(8.49 \mathrm{KM} /$ litre) or the 1990 level of 8.49 (Table 1). The on road fuel economy in 1973 is higher at $10.41(\mathrm{KM} / \mathrm{L}) .{ }^{2}$ This is the case despite improved fuel economy standards for new vehicles and a highly taxed vehicle ownership system.

The lack of accelerated improvement in on-road fuel economy has led to rapid growth in gasoline consumed, in turn, increasing Japan's oil dependency and its vulnerability to oil price shocks. As shown in Table 1, the transport sector (all modes) consumed $54 \%$ of total petroleum products in 2008 representing an increase from the 1973 share of $35 \%$ and from the 1980 share of $41 \%$ (IEEJ 2010). ${ }^{3}$ Motor fuel use (mainly gasoline and LPG) accounts for half of total energy use in transport in 2008. Japan's motor fleet continues to grow in importance in terms of its overall energy use, emissions of greenhouse gases, local air emissions and weight in the economy. ${ }^{4}$

\footnotetext{
2 This implies that on-road fuel economy is $41.4 \%$ below new car fuel economy. Sano (2008) reports a fuel economy gap of $30 \%$ for 2005 , implying that on-road fuel economy is equal to $70 \%$ of new car fuel economy. Schipper (2007) reports a gap of $38.7 \%$ using a figure of $15.34 \mathrm{~km} / \mathrm{l}$, of new cars, and $9.43 \mathrm{~km} / \mathrm{l}$ for on-road cars, for 2005 and of $28 \%$ for 1995 . Recent figures show a slight improvement in on-road fuel economy perhaps owing to the rising market share of mini cars.

${ }^{3}$ In Japan motor fuels consumption accounts for the largest proportion of energy consumption of the transport sector. LPG and diesel car fleets have increased but their market share remains low. For example the share of LPG fell from $6 \%$ of total fuel consumption to $4 \%$, in 2005, and diesel from $12 \%$ to $6 \%$. Diesel cars (more fuel efficient) are less popular in Japan than in Europe.

${ }^{4}$ In 2003, the entire transport sector (private vehicles, freight vehicles, shipping and aircraft) is responsible for almost one fourth (23\%) of Japan's $\mathrm{CO}_{2}$ emissions with private vehicles accounting for $14 \%$ of total CO2 Japanese emissions IEEJ (2003; pp.38 and 223).
} 
Standard top-down models (of a numerical or econometric bent) of gasoline demand, and vehicle energy efficiency, do not link changes in physical depreciation (decay rates) of fuel economy (of new cars) to changes in vehicle stock and vehicle sales; a common practice is to simulate changes overtime in gasoline demand separately from vehicle sales and of vehicle size for entire vehicle stocks. This paper uses disaggregate data on vehicle sales to fill those deficiencies in the literature of gasoline demand models.

\section{Research framework and data}

\subsection{Gasoline demand model: A review of studies}

Our paper provides several advances beyond the existing literature on gasoline demand models. First, our data set includes national sales of inefficient and efficient cars for 1980-2008 years, the price of these classes, household income, gasoline prices and vehicle use by vehicle class. The data allows us to ask questions regarding why consumers choose to buy a mini or a larger car and then to project gasoline demand. The second contribution is that we propose a model of gasoline demand that interacts with vehicle sales changes. To our knowledge this is the only study that examines disaggregate fuel economy effects on gasoline demand using this data set.

Studies of gasoline demand have been numerous and the field has been heavily researched. Espey (1998) reviews the field as far back as 1929. However, many of the key findings on the behaviour of gasoline demand are based on studies with a top down approach covering the 80s, and before, as pointed out in Hughes et al. (2009). There is reason to believe that because of structural changes in the vehicle market gasoline demand has too changed and so to accurately predict gasoline demand it is best to apply a disaggregate model, within a bottom up perspective, of gasoline demand as we do in this paper. 
Unlike our model (section 3 onwards), top down models of gasoline demand do not incorporate vehicle characteristics, nor vehicle market dynamics, neither vehicle stock changes across time and space. Top-down models of gasoline demand are described in Dahl (1995) Graham and Glaister (2002).

Many studies do not take into account the heterogeneity of the vehicle market (Gately (1990), Johansson and Schipper (1997) and Small and Van Dender (2006). Johansson and Schipper (1997) is the only study that compares the effect of taxes on gasoline demand over a sample of the OECD, however, the study did not incorporate the disaggregation used in our study. The Small and Van Dender study introduces a gasoline demand model using vehicle stock effects via simultaneous model with $\mathrm{km}$ driven, vehicle stock and aggregate fuel economy for the 1966-2001 years. These studies are not, however, sufficiently disaggregated and so it is difficult to provide policy advice using models from the top-down perspective.

Blomqvist and Haessel (1978) estimate how much gasoline demand can be mitigated by stimulating sales of fuel efficient cars. Bonilla (2009) estimates aggregate fuel economy (by fuel type for on road cars) for the British experience. In an exceptionally large study, Busse et al. (2009) examine the car market of new and of used cars to estimate the market shares and to predict fuel economy by model type for the US case. These studies have the drawback of ignoring dynamic vehicle price effects on the demand for small and mini cars, nor do studies use data samples for many decades to represent income effects on the demand for efficient cars.

A model similar to ours is the study of Sakaguchi (2000) but our study differs because we incorporate time series data in our analysis, and represent the 'real' technical progress using data on the historical change of new car fuel economy within 1980-2008 by class of vehicle. ${ }^{5}$

\footnotetext{
${ }^{5}$ Baltagi and Griffin (1983) are exceptional studies in that they estimate the effect of car fuel economy on gasoline demand for OECD economies but this is also an aggregate fuel economy study.
} 
Gasoline demand has been estimated using numerous econometric techniques (co integration, dynamic panel models, qualitative choice, cross sectional, error correction) and with single or simultaneous equations. Recent studies have relied on ever larger data sets and more sophisticated econometric models but the approach continues to be top-down.

The following studies do not examine changes, at a decade level, of vehicle characteristics Schmalensee and Stoker (1999); Kazimi (1997), Oladosu (2003), Archibald and Guillingham (1980); Kayser (2000); Greening et al. (1995) Nicol (2003). An exception is the work by Barla et al. (2009) whose estimates are based on recent historical data on fuel efficiency, vehicle mileage and the rebound effect. Historical changes (e.g changes beyond the span of a decade) in car markets are closely connected to the today's level of new car fuel economy and of gasoline demand but this is commonly ignored in much of the literature. Innovative work (Greene, 2010) using the reference dependent choices paradigm to explain why consumers underinvest in fuel economy i.e loss aversion or reference dependent choices, uncertainty in fuel prices and in vehicle use. This paradigm complements the more traditional insights, of gasoline, that correlate vehicle sales to household budget, fuel expenditures, mileage, fuel prices. Our paper quantifies the investment decision for fuel economy.

A further innovation of this paper is that we assume that fuel economy degrades overtime as in Fischer et al. (2007) and we adopt the same approach to explain how vehicle age lowers engine performance. We improve upon previous models of gasoline demand, by breaking up the components of demand with observed vehicle types, household income, car usage, vehicle size and vehicle age. For example, sales for new vehicles with lower fuel economy (fewer KM per litre of fuel ) have gained market share in recent years. To our knowledge this is the first study that disaggregates gasoline demand and that links such demand to changes in vehicle sales using time series data for the small, mini and standard car classes. 


\subsection{Trends in vehicle sales: Japan's passenger cars}

Figure 2 depicts the time trend of annual sales (in million vehicle registrations) of mini, small and medium-large (standard) cars; total sales (all vehicles) peak in 1990. Figure 2 highlights the upward trend in mini-car sales (with fuel economy of $17 \mathrm{Km} / \mathrm{L}$ ), the decreasing trend in sales of small cars (with fuel economy of $15 \mathrm{Km} / \mathrm{L}$ in 2001) and the increasing trend in sales of standard cars (with fuel economy of $9.85 \mathrm{Km} / \mathrm{L}$ ). The latter trend can increase car weight, in turn, decreasing the fuel economy of larger cars. Large (standard) cars are those with a $2000 \mathrm{cc}$ (cubic centimetres) engine; small ones with $>660 \mathrm{cc}$ engine but $<2000 \mathrm{cc}$; and mini cars with less than $660 \mathrm{cc}$.

Figure 2 also shows that new car sales (all vehicles) increased strongly in 80 s and later stabilise around 3.9 million registrations per year in 2008. It is clear from Fig. 2 that sales of the energy intensive cars are now higher than in the 1980's following the entry of larger engines into the vehicle stock. Mini vehicles have been defined by engine size but that size has been altered since 1989 allowing relatively larger vehicles to qualify as "mini". ${ }^{6}$ For example, the share of (new) small vehicles, in the entire Japanese vehicle fleet, fell from $87 \%$ in 1990 to $45 \%$ in 2003 as consumer preferences shifted from small to larger vehicles (JAMA, 2008). These changes in market shares of cars have conspired to prevent the reduction in gasoline demand overtime.

\footnotetext{
${ }^{6}$ Santini (1994; pp. 23) notes that from 1976 to 1989 mini-sized cars were defined as those with $550 \mathrm{~cm}^{3}$ engines; after 1989 mini cars with engines of size $660 \mathrm{~cm}^{3}$ were still classified as mini-sized cars.
} 


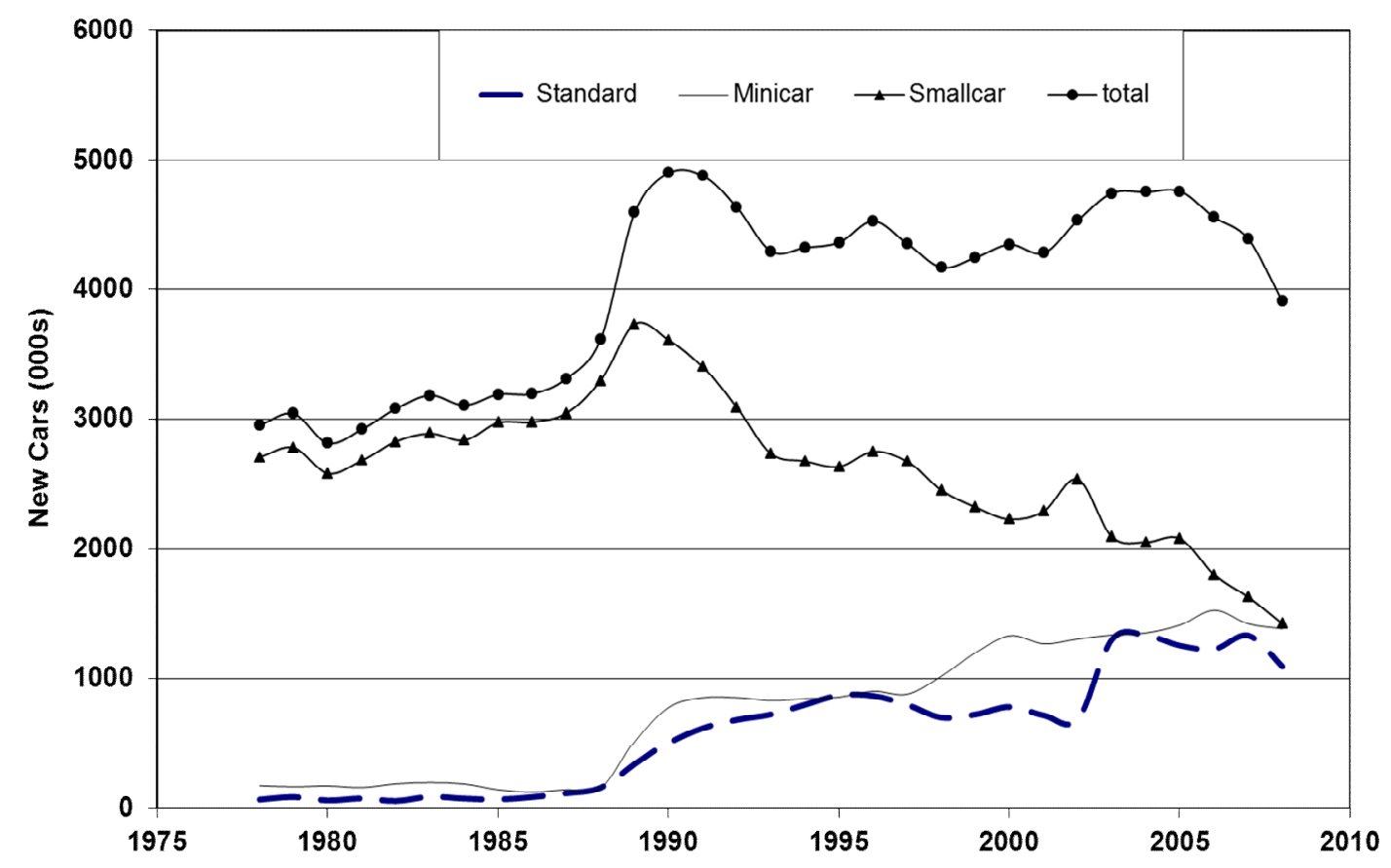

Figure 2. Vehicle sales in Japan (by class). Source: IEEJ, 2010

The increase in the sales of mini cars is real and not only a result of the changed definition. The increase in sales occurs during the 80 s rather than in the 90 s when sales are more stable and the volume of sales is large by international standards.

The data on fuel economy of new cars (mini, small and standard) are plotted in Figure 3 in time series form: The data are used in our model of gasoline demand (Figure 1). The mini car offers the best fuel economy out of all three car types; the mini has a fuel economy performance of more than $20 \mathrm{KM} /$ litre (gasoline), a substantial advantage from the fuel economy of a standard car. Fuel economy is assumed to increase by $1 \%$ year in the projection period, following the historical average. In section 3 we explain how these projections are produced (fig. 2 and fig.3). 


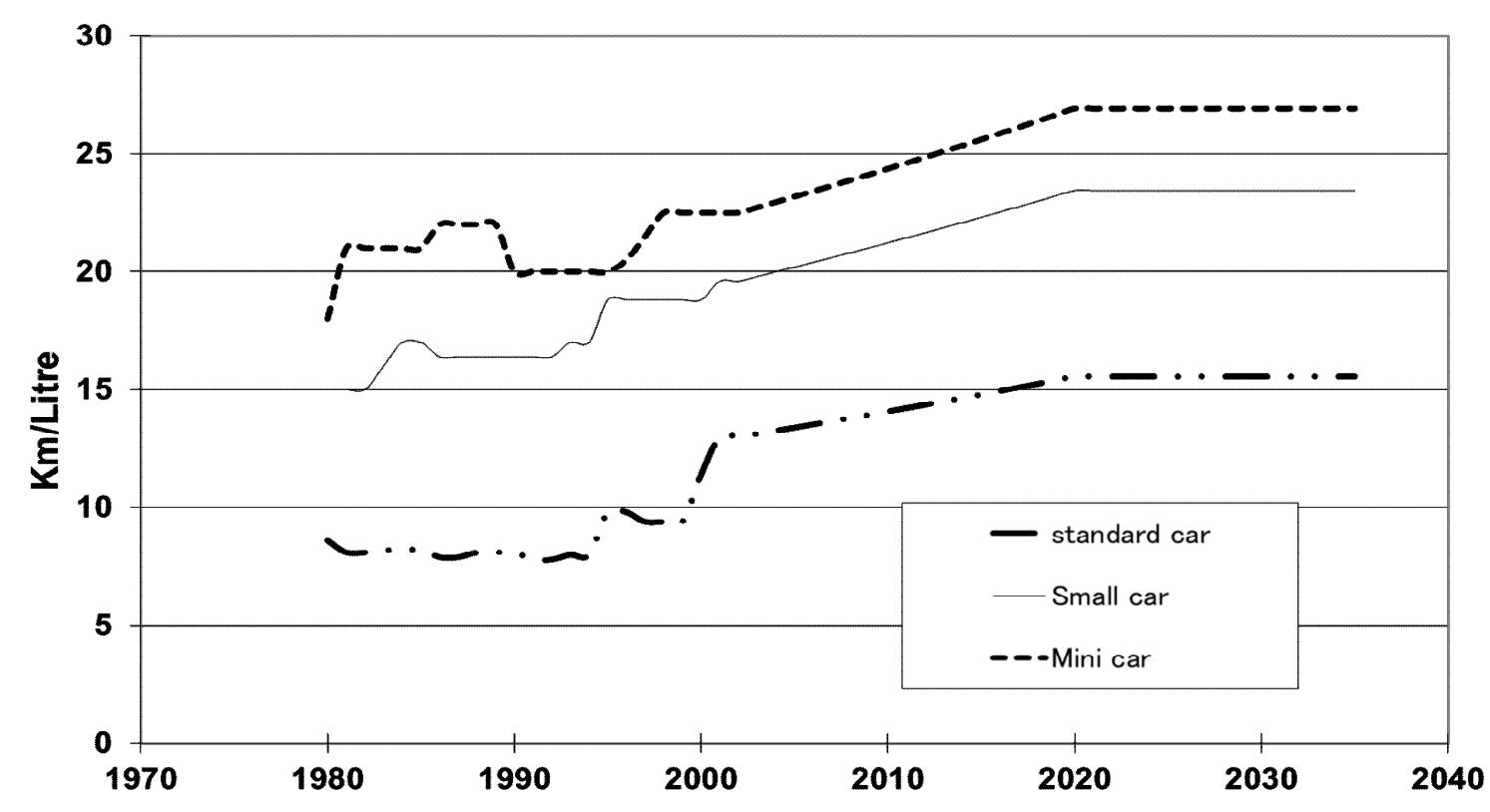

Figure 3. New car fuel economy (by class). Source: Japan Automobile Manufacturers Association, 1985-2003 (10.15 drive cycle test. Source: this author for years 20022020.

In the following sections we introduce a gasoline model that simulates how difficult it can be to reduce gasoline demand if the sales of more efficient cars decline while those of standard ones, and less fuel efficient, increase. In our model, sales of small cars fall which, in turn, leads to a decline in their vehicle stock translating into less fuel saved. Although the effect of vehicle stock of small cars outweighs that of mini car, the model predicts a decline in aggregate gasoline demand to 2021 followed by a subsequent increase by the year 2035 .

The gasoline demand model, applied to data on three vehicle types and results presented in this paper, enables a detailed examination of car market trends and policies that affect gasoline demand, on-road vehicles and key technological characteristics that determine on-road fuel economy. ${ }^{7}$ It is tailored to capture predicted changes in vehicle sales, by size class, and vehicle prices as well as household income growth, all of which impact on gasoline demand. The complete model is made up

7 The literature has consistently modeled fuel economy change by means of a time trend overlooking the importance of endogenising actual changes of car fuel economy in a model of gasoline demand (Bonilla 2006). 
of numerical equations (inputs) producing vehicle stock and econometric equations using time series data. The first step involves developing model inputs (for vehicle stock, and new car fuel economy) and estimations (by Ordinary least squares) of vehicle sales. Estimations for vehicles sales feed the vehicle stock projections. Both projections of vehicle stock and of new car fuel economy feed the gasoline demand models. Projected car sales feed the vehicle stock numerical solution to 2035 .

In addition, unlike the cited literature, our model of gasoline demand is a multi-equation system, that considers, explicitly, historical change in new car fuel economy levels by vehicle class, and distinguishes between large and small vehicles stock. Our model draws on data of 16 data items (time series) that span over two decades. ${ }^{8}$ To our knowledge few studies have simultaneously simulated such effects on gasoline demand, at least for Japan.

\section{Overview of Methods and model structure}

The model is split into a set of numerical equations and econometric relationships. Numerical equations provide the forecasts using econometric results. We first estimate vehicle stock and the surviving vehicle stock, using sales data by vehicle class size and scrappage. Second, we estimate market shares by class size of more or less efficient cars. We, then, simulate gasoline demand after accounting for the effects of VKM- driven, surviving car stock and the weighted mean of new car fuel economy. Sales and car stock are projected to the year 2035 by using the calculated

\footnotetext{
${ }^{8}$ Studies also fail to incorporate the effect of fuel economy of the car stock on such demand. In contrast to those studies the effects of the vehicle stock and vehicle fuel economy in this work are modelled to project gasoline demand.
} 
coefficients from the time series equations and by allowing for fuel economy improvements in the fleet of such vehicles.

\subsection{Estimating the stock of Japanese vehicles}

Gasoline demand is a derived demand since it depends on the stock of gasoline fuelled vehicles. In this section, we explain how vehicle sales and vehicle stock are simulated. Below, we estimate a demand function of vehicle sales by econometric equations.

Economic theory suggests that the vehicle stock is a function of past investment (in vehicles), the utilisation rate of older vehicles, investment (sales) in new vehicles and their current utilisation (Berndt and Botero, 1983; pp. 5). For this reason total investment (car stock) needs to be estimated. In this formulation, vehicle sales act as inputs to estimate Japan's vehicle stock to 2035 . We estimate the surviving vehicle stock assuming such stock is a function of vehicle sales using survival rates of vehicles that vary with the age of the vehicle. Vehicle age is used because it determines (a) physical wear and tear and (b) the quantity of vehicles that are scrapped, as described in Greenspan and Cohen (1996). Stock models (Eq. 1) allow us to estimate how quickly old vehicles (less fuel efficient) are replaced by new vehicles (more fuel efficient).

\subsection{Surviving vehicle stock}

The model starts at the level of vehicle sales (observed and actual sales) for year " $\mathrm{i}$ " for three different vehicles as:

$$
V_{i k}^{\text {sales }}
$$


Where $\mathrm{i}$ is the year of observation $(1978<\mathrm{i}<2035)$ and $\mathrm{k}=1,2,3$ is the vehicle type, standard, small or mini, respectively.

Domestic vehicle sales (actually observed sales) in Japan (figure 1), start from $1978<\mathrm{i}<$ 2007. Vehicle sales are forecasted, in the next section, for $2008<\mathrm{i}<2035$ using a set of estimated econometric equations. Domestic vehicle sales are plotted in Figure 2.

We define the vehicle stock in the year i as follows.

$$
S_{i, j, k}
$$

where $\mathrm{j}$ is the years of use of the vehicle since it was acquired. We assume that cars are scrapped when they reach 18 years old, hence

$$
\begin{array}{r}
0<\mathrm{j}<18 \\
S_{i, j, k}=0 \text { for } j>18
\end{array}
$$

Integrating the vehicle stock and vehicle sales, we have

$$
S_{i, 0, k}=V_{i, k}{ }^{\text {sales }}
$$

and using survival rates of vehicles (based on US data in Davies and Diegel, (2007), we have:

$$
S_{i+1, j+1, k}=\left(S_{i, j, k}\right) \gamma_{j, k}
$$

We use subscripts in order to represent the stock of vehicles of Japan. For example, to work out the total vehicle stock (all vehicles)s in the year $\mathrm{i}$, we have

$$
S_{i}=\sum_{j=0}^{18} \sum_{k=1}^{3} S_{i, j, k}
$$


Function 1 is applied to data for years 1978 to 2035 and this function assumes the vehicle stock begins in 1978; in other words vehicle stock is equal to vehicle sales in 1978. For example, for vehicles surviving into 1996 car sales data for 1978, through 1996 are multiplied by a survival rate (as in Eq. 1) yielding the surviving vehicle stock in years 1996. Equation 1 is plugged into Eq. 1.1 into a dynamic equation of vehicle stock where vehicle stock, of age $\mathrm{j}$, is a subset of surviving vehicle stock. The total surviving vehicle stock for say 1996, is the sum (Eq. 1.1) of vehicle stocks of ages 0 to 18 of $\mathrm{k}$ vehicle. For example, survived vehicle stock of age 1 is computed by multiplying the previous year's car sales (year 1995) times its corresponding survival rate. The vehicle stock and gasoline demand models are solved in a spread-sheet format.

Surviving vehicle stock (Eq. 1.1) yields the vehicle stock. Total stock for any year would be the sum of the three stocks (of three vehicle types). To project the growth of vehicle stock by size to the year 2035 as shown in Eq. 1 vehicle sales are first determined by using a time series equations (Table 4). Relevant data is available in (JAMA, Handbook, (2008) as well as in IEEJ (2010). The time-series data is derived on the basis of actual data for only 3 vehicle types for 1980-2007 years. Fitted data for vehicle sales are obtained through estimated equations and it is these figures which are then added to surviving vehicle stock. Projections of vehicle stock (by type) are subsequently fed into gasoline demand equations described below.

\subsection{Decay in fuel economy of new cars and Gasoline demand}

Data of new car fuel economy (Figure 3) is taken from car manufacturer sources (JAMA Handbook, 2008). Using the data obtained from Japan and assuming that the efficiency (fuel economy) of the vehicles in future years improves by $1 \%$ per year 2008 2035, we obtain Figure 3. 
An extra layer of uncertainty is introduced (Eq. 2 and 3)to capture a the decaying effect of new car fuel economy on total gasoline demands. Because the fuel economy of an older car, say, a 9 year old car is significantly below that of a brand new one, an extra variable is introduced for physical depreciation:

$$
E_{i, j, k}=E_{i, k} \times \theta_{j}
$$

where $E_{i, j, k}$ is new car fuel economy of k vehicle, of $\mathrm{j}$ years, of $\mathrm{i}$ year of observation; $\theta_{j}$ is a depreciation (given in percent) of the engine's car, for $\mathrm{j}$ years of age, and represents the decay in fuel economy over time. Using the following expression we get:

$$
\theta_{j+1}=(1-\phi) \theta_{j} \text { for } 0 \leq \theta_{j} \leq 1
$$

where $\phi$ is the depreciation rate (given in percent) of the efficiency of the engine's car. For example, if $\phi$ takes a value of $1 \%$ (per year), by the time a car is 18 years old, the decay in its fuel economy (efficiency) will be $83 \%$ of the fuel economy of a brand new car. (This is a conservative assumption as efficiency of engine can decline even more with the effect of time. Hence, it is assumed that fuel economy declines by $1 \%$ for every extra year in vehicle age). The $1 \%$ assumption is based on historical average improvement in new car fuel economy.

The calibration of gasoline demand by vehicle class is determined, on the basis of co-dependent economic and technological relationships, as follows. In Eq. 4 Gasoline demand is obtained by an equation that includes the ratio of the product (vehicle stock times average KM-driven per vehicle), to fuel economy of the new car stock for the kth vehicle.

Gasoline demand forecasts are obtained by applying Eq. 4 and assuming fuel economy by class of vehicle, once projections have been performed on vehicle stock ( Eq. 1) and usage:

Aggregate gasoline demand, $G$, can be calculated as: 


$$
G_{i, j, k}=\left[\frac{S_{i, j, k} \times \beta_{i, k}}{E_{i, j, k}}\right]
$$

where $\beta_{i, j}$ is the average kilometers driven per vehicle at year $\mathrm{i}$ for every type of vehicle k. Eq.5 completes the picture. Again using the definition in our model, we can compute the total gasoline consumption of the Japanese vehicle stock by:

$$
G_{i, k}=\sum_{j=0}^{18} G_{i, j, k}
$$

As we show in the next sections fuel economy of new cars (denoted by E, in Eq. 4) is forecastable to 2035 . The fuel economy variable is used subsequently to project gasoline demand, by vehicle size, to 2035 . Equation 5 is applied to stock data for every year starting from 1978 to 2035 for all vehicles.

Total gasoline demand, involving vehicles $\mathrm{k}$ of ages $\mathrm{J}$, is simulated by applying Eq. 5 . We calibrate to existing totals for a specific years.

Equation 4 includes the vehicle stock and household effects and behaviour of drivers. (KMdriven per car and per year). Each of the variables of Eq. 4 are forecastable to the year 2035. As shown in Baltagi and Griffin (1983, pp. 119) Eq. 4 has the advantage of incorporating both short (mileage) and long run effects (fuel economy). In particular, car fuel economy effects need a long period to have an impact on vehicle stock while effects on usage may take place using the same car stock. It should be noted that Eq. 4 uses past fuel economy of new vehicles to calculate gasoline demand. This equation computes gasoline demand for vehicle stock $\mathrm{k}$ that survives at every vehicle age j. Each model year is linked to past fuel economy. In other words simulated gasoline demand 
accounts for the profile of past fuel economy levels and current. The estimation of gasoline demand of both small cars and mini cars is conducted similarly.

\subsection{Vehicle sales regressions}

To work out vehicle stocks as explained in section 3.2 vehicle sales need to be forecast to 2035 . Regressions are estimated to explain Japan's demand for cars (by class size) using the following explanatory variables in logarithms: real car price index divided by (real) household income, (real) gasoline price, km-driven (kilometres per vehicle "in use"), and a time trend. Data is collected for household income based on GDP data from IEEJ (2010) and number of households from National Institute of Population and Social Security (2010). Vehicles sales data is sourced from JAMA Handbook (2008). KM-driven from (IEEJ, 2010), gasoline price from (IEEJ, 2010) and capital cost of vehicles from the Japan Statistical Bureau (2010). Table 2 depicts the summary of statistics of data for the econometric analysis. Appendix A shows the data used for this analysis.

Table 2. Descriptive statistics of vehicle sales equations

\begin{tabular}{|c|c|c|}
\hline & Mean & Standard deviation \\
\hline Sales 000's Standard) & 394.0 & 155.09 \\
\hline Sales 000's (Small) & 2873 & 594.75 \\
\hline Sales 000's (mini) & 473 & 417 \\
\hline Capital cost (index) & 119.0 & 20.79 \\
Standard & & 21.13 \\
\hline Capital cost (index) & 113.72 & \\
\hline Small & & 20.14 \\
\hline Capital cost (index) & 113.83 & \\
\hline
\end{tabular}




\begin{tabular}{|c|c|c|}
\hline Mini & & \\
\hline Household income & 10647.03 & 1021.59 \\
\hline Km/car & 10038 & 177.58 \\
\hline Gas price & 129.52 & 32.54 \\
\hline
\end{tabular}

The following was done (eq. 6) to estimate joint hypothesis for each of the three cases (by class of vehicle). The long run regression for car sales for the unrestricted model is:

$$
\begin{aligned}
& \ln \left(\text { sales }_{k}\right)=\alpha+\beta_{1} \ln \left(\cos t_{k} / \text { Hinc }\right) \\
& +\beta_{2} \ln (\text { Gasp })+\beta_{3} \ln \left(K m_{k}\right)+\beta_{4} \text { trend }+\varepsilon_{t}
\end{aligned}
$$

Where sales is vehicle sales; cost is cost of the vehicles; Hinc is real household income; Gasp is gas price and $\mathbf{K m}$ VKM driven by car for $\mathrm{k}$ (mini, small and standard) vehicles; and an error term represented by epsilon. Table 3 shows the results of equation 6 . L stands for natural logarithms and the coefficients of eq. 6 can be seen as long run elasticities of car sales. The elasticities that equation 6 produces can provide evidence on whether consumers underinvest or not in fuel economy over the 1980-2008 period. 
Table 3.

Time series model of vehicle sales: 1980-07. Dependent variable: vehicle sales. Estimated by SPSS software. Long run model for vehicle sales

\begin{tabular}{|c|c|c|c|}
\hline & $\begin{array}{c}\text { Standard } \\
\text { Vehicle } \\
\text { (a) }\end{array}$ & $\begin{array}{c}\text { Small } \\
\text { vehicles } \\
\text { (b) }\end{array}$ & $\begin{array}{c}\text { Mini } \\
\text { vehicles } \\
\text { (c) }\end{array}$ \\
\hline Intercept & 118.02 & 131.65 & 196.3605 \\
\hline $\begin{array}{c}\log \text { of } \mathrm{CAPCO} \div \mathrm{HI} \\
\text { t-value }\end{array}$ & $\begin{array}{l}-5.34 * \\
(-7.44)\end{array}$ & $\begin{array}{l}-1.23 * \\
(-3.35)\end{array}$ & $\begin{array}{l}-4.75^{*} \\
(6.74)\end{array}$ \\
\hline $\begin{array}{l}\log \text { of GP } \\
\text { t-value }\end{array}$ & $\begin{array}{r}0.50 \\
(0.71)\end{array}$ & $\begin{array}{l}0.64 * \\
(1.83)\end{array}$ & $\begin{array}{l}1.20^{*} \\
(1.49)\end{array}$ \\
\hline $\begin{array}{c}\log \text { of VKM-driven } \div \\
\text { vehicle stock } \\
\text { (vehicle class) } \\
\text { t-value }\end{array}$ & $\begin{array}{l}-1.24 \\
(0.07)\end{array}$ & $\begin{array}{l}0.09 \\
(0.06)\end{array}$ & $\begin{array}{l}0.81 * \\
(3.30)\end{array}$ \\
\hline $\begin{array}{l}\text { time trend } \\
\text { t-value }\end{array}$ & $\begin{array}{l}-0.04 * \\
(-1.71)\end{array}$ & $\begin{array}{l}-0.06^{*} \\
(-3.83)\end{array}$ & $\begin{array}{c}-0.096^{*} \\
(1.52)\end{array}$ \\
\hline $\operatorname{Adj} . R^{2}$ & 0.97 & 0.50 & 0.96 \\
\hline DW & 1.00 & 0.54 & 0.70 \\
\hline Period (all equations) & \multicolumn{3}{|c|}{ 1980-07 } \\
\hline \multicolumn{4}{|c|}{$\begin{array}{l}\text { Values in() are }=\text { t statistics. Notes: Data: annual time series. HI: household income; CAPCO: } \\
\text { capital cost by vehicles class. GP: real gasoline price; total VKM-driven: km per car per year. } \\
\text { The model for mini cars includes (column c) VKM-driven only (ignoring vehicle use), unlike } \\
\text { models "a" and "b". } \\
\text { The F-test accepts the first equation since the F-ratio is larger than the tabled F value. } \\
\text { Number of sample observations: } 27 \text { * denotes a statistical significant coefficient at } 5 \% \\
\text { significance level. }\end{array}$} \\
\hline
\end{tabular}

Table 3 shows the econometric results of logged car sales using time series data for 1980-07 following equation 6 to represent vehicle sales responses. Results show that most fitted equations explain more than $90 \%$ variation of vehicle sales, with high $\mathrm{R}^{2}$ statistics except for the small car 
equation. The t- tests also reveal that the fraction of capital cost to household income is statistically significant from zero (Table 3). The estimated equations (Eq. 6) also show that most key variables are highly statistically significant. The key coefficients (capital cost), and in most equations, show the expected sign for all vehicle classes. These results (table 3) can, however, be spurious or non authentic and so other models are also built to remove the non stationarity characteristics of the data series. Non stationarity arises if one of the explanatory variables is trending upwards or downwards (Thomas, 1997, p. 373) and where its mean, variance and covariances are not constant over time. The first difference models are shown in Table 4.

The values in Table 3 indicate strong autocorrelation for all three models and so these are not used to project vehicles sales to the year 2035. An examination of the data series used in the estimation of equation 6 indicates nonstationarity or the presence of a unit root. The nonstationarity feature in the data series is revealed by the Augmented Dickey and Fuller tests; the tests value ranges from -2.2. to 2.56 which is not negative enough to reject nonstationarity in the series. Table 2 tabulates the data series that are used in this analysis.

Since the equations shown in table 3 are found to have non stationarity properties, that is the data series do not return to their long run mean, the estimation strategy to project vehicle sales now relies on models for the proportionate change in sales of vehicles $\mathrm{k}$ (Table 4).

Table 4 shows the short run estimates which are computed by using a model of first differences to explain vehicles sales. The elasticities are statistically significant ( $t$ value $>1.6$ ) but only for a few variables. The first difference model, to represent the proportionate changes in sales of $\mathrm{k}$ cars, is explained in the equation below.

Where, 


$$
\begin{aligned}
& \Delta\left(\text { sales }_{t}\right)=\left(\text { sales }_{t}-\text { sale }_{t-1}\right) \\
& \Delta\left(\text { cap }_{t}\right)=\left(\cos t / \text { Hinc }_{t}-\cos t / \text { Hinc }_{t-1}\right) \\
& \Delta \operatorname{Gasp}_{t}=\operatorname{Gasp}_{t}-\text { Gasp }_{t-1} \\
& \Delta K m_{t}=K m_{t}+K m_{t-1} \\
& k=\text { vehicle type }(\min i, \text { small, } s \tan d a r d) \\
& \Delta=\text { first difference } \\
& t=\text { year } ; t-1=\text { previous year }
\end{aligned}
$$

And coefficients,

$$
\begin{aligned}
& \beta_{k}=\text { regression coefficients } \\
& v_{t}=\varepsilon_{t}-\varepsilon_{t-1}
\end{aligned}
$$

$$
\begin{aligned}
& \Delta\left(\operatorname{sales}_{k t}\right)=\alpha+\beta_{1}\left(\Delta \operatorname{Cap}_{k t}\right) \\
& +\beta_{2}\left(\Delta \text { Gasp }_{t}\right)+\beta_{3}\left(\Delta K m_{k t}\right)+\beta_{4} \text { trend }+v_{t}
\end{aligned}
$$

The decision rule is that if buyers of mini, or small cars, react negatively to increases in capital cost or to gasoline price they underinvest in fuel economy and gasoline demand will be higher in the long run. If those buyers do not react negatively to price changes they invest in fuel economy.

Table 4.

Coefficients fit of the model, Diagnostic and Forecasts tests for the model estimated over the 19802008 Sample. Short run elasticity Values are produced by the first differences model for sales. $T$ values in brackets. The table reports standardized coefficients in standard deviation units. Estimated by SPSS software.

\begin{tabular}{|l|l|l|l|}
\hline & Large & Small & Mini \\
\hline$\Delta$ Capco $\div \mathrm{HI}$ & 0.028 & -0.538 & 0.685 \\
& $(0.111)$ & $(2.639)$ & $(3.037)$ \\
\hline$\Delta \mathrm{GP}$ & 0.007 & -0.059 & -0.01 \\
& $(0.034)$ & $(0.336)$ & $(0.06)$ \\
\hline
\end{tabular}




\begin{tabular}{|l|l|l|l|}
\hline$\Delta \mathrm{Km} /$ stock & 0.111 & 0.101 & 0.083 \\
& $(0.449)$ & $(0.597)$ & $(-0.391)$ \\
\hline Trend & -0.007 & -0.031 & 0.340 \\
& $(-0.025)$ & $(0.153)$ & $(1.484)$ \\
\hline $\mathrm{R}^{2}$ (adjusted) & -0.16 & 0.280 & 0.206 \\
\hline Durbin Watson & 1.83 & 1.17 & 1.39 \\
\hline Observations & 28 & 28 & 28 \\
\hline
\end{tabular}

Fitted equations (Tables 3 and 4) give the consumer response of sales with respect to capital cost as a proportion of household income. A ratio is used to capture the capital cost effect on the purchasing decision (vehicle sales variable) since the variables on the right hand side are highly collinear (eq. 6and 7). Inclusion of capital costs in sales equations follows the approaches of Lave and Train (1979); Mannering and Mahmassani (1985) and McCarthy (1996).

The econometric evidence points that car buyers will underinvest in fuel economy in the case of the mini car class (Table 3) since capital cost is associated to an decrease in sales of this specific car class. In addition there is evidence that consumers will underinvest in fuel economy in the long run since sales of small cars are negatively associated to increases in capital costs in the 1980-2007 period (Table 3). Sales of large cars, however, are not negatively affected by increases in capital costs in the short run.

The effect of capital cost is found to be largest effect on car sales in the short (equation 7) and long run models (See Table 3 and 4). The coefficient on capital cost is statistically significant from zero and it is the largest coefficient in all equations; the calculated t value is greater than 1.6 at a $5 \%$ significance level which allows to reject the null hypothesis of no effect of this variable on vehicle sales. The coefficient on capital cost ranges from a unitary price elasticity $(-1.23)$ to a highly elastic 
response (-5.34) using log-linear equation without first differences. The vehicle cost elasticities of Table 3 are inside the range of studies for the U.S car market; the latter elasticities lie between -0.51 to -6.13. [Lave and Train (1979); Mannering and Mahmassani (1985; McCarthy, 1996)]. In short the econometric evidence shows that vehicle capital cost has been the key consideration, in the last three decades, for car choice among Japanese buyers.

The estimated equations indicate (Table 3) that an increase in sales of larger cars is in order if people drive longer distances (KM-driven) (or as they use their cars more). Vehicle size is sensitive to gasoline price changes in the 1980-07 period: higher gasoline prices encourage mini car sales because such cars are fuel efficient and so these save running costs. Therefore, the higher the fuel prices are the higher the sales of fuel efficient cars will be. This shows the importance of raising fuel prices so that buyers favour fuel efficient cars (the mini or the small car).

Table 3 shows that energy rebound effects appear in the small and in the mini car equations, which means that a recovery in demand for gasoline is in order for personal transport in Japan. Substitution effects show that if consumers buy standard cars they will also buy mini cars (cross elasticity of minus 5.42) but if consumers buy mini cars they will switch away from small cars. Substitution estimates also reveal that consumers switch from the small to the large car (cross price elasticity of 0.42 ). These substitution possibilities will change if Japan's population ages even more and if the composition of the vehicle stock changes in next decades. The models presented in table 3 show that substitution possibilities among buyers of small, mini and standard cars is a key parameter to explain the future level of fuel economy of new car fleets and of future gasoline demand. The growth in the stock of large cars also increases the demand for gasoline more than in the previous decades when the small car dominated the Japanese car market. 


\section{Results: Projections for vehicle sales by vehicles class}

\subsection{Vehicle sales and gasoline demand 2035}

Our projections on vehicle sales (Figure 4) shows that the small car class will continue to lose market share whilst the other two vehicle types gain market share; the overall demand, however, for motor fuels does not decline by 2035 (Figures 5, 6 explain this point further below).

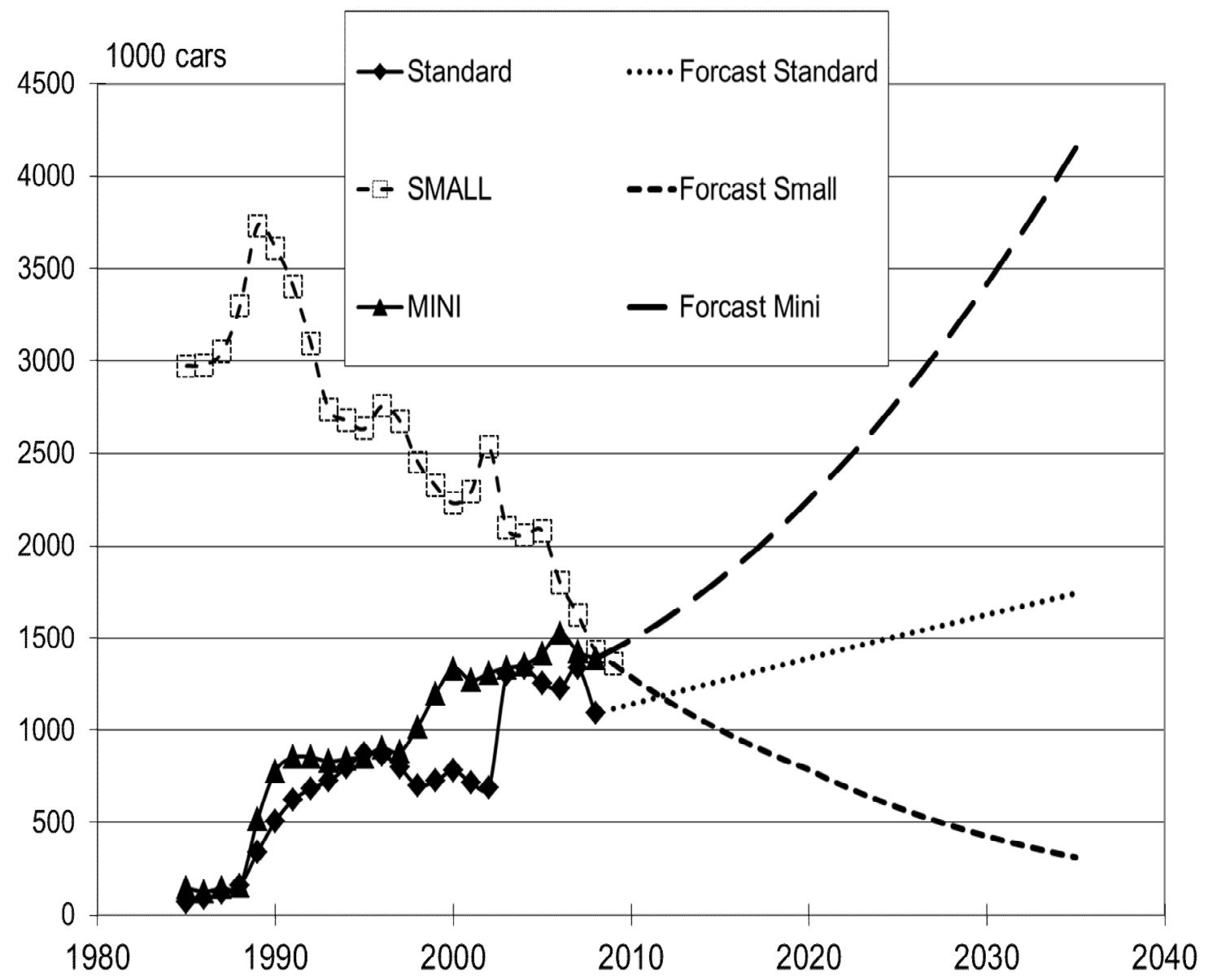

Figure 4. Projections for vehicle sales new cars: small car loses market share.

Our projection methodology, for vehicle sales, is explained in section 3. 


\subsection{Forecasting vehicle stocks for Japanese cars}

Following the projection of vehicle sales to 2035 (based on the estimates reported in Table 4) and the application of Eq. 5, projections can be made for vehicle stock to 2035 (by applying the vehicle stock model (Eq. 1 and 1.1). Projections for gasoline demands (Eq. 4 and 5) can also be produced based on equations 1 through 5 for each vehicle type. Two projections are proposed. The first of these reveals the level of gasoline demand whilst fuel economy decays over time (labelled DFE); while the second projection relies on the assumption that vehicle fuel economy will not decay in the 2008-2035 period (labelled FEI). All projections take into account the low rate of growth in new households as Japan's population continues to age.

\section{Assumptions of gasoline demand}

The projections require a number of assumptions on:

1. Household income (using published forecasts on real GDP by IEEJ [46];

2. Vehicle sales and vehicle stock and vehicle use (using Eqs. 1-1.1;7);

3. Vehicle fuel economy by vehicle class (Eq. 2, 3 and 4);

4. Car price by vehicle class;

Figures 4 and 5 show the assumptions and outcomes. Table 5 tabulates the assumptions that are used to build the projections.

Table 5. Assumptions for gasoline demand 2008-2035

\begin{tabular}{|l|c|}
\hline & High growth (\%/year) \\
\hline GDP growth (\%)) & 1.1 \\
\hline Households (number) & 0.2 \\
\hline Capital cost (vehicle class) & constant \\
\hline Vehicle-Km per car (Use) & constant \\
\hline
\end{tabular}




\subsection{Projection for gasoline demand by vehicle class}

Figure 5 describes the projection for the entire gasoline demand of Japan by vehicle size 2008-2035 and it is assumed that fuel economy of new cars decays over time. Figure 5 is a result of the equations (Eq. 1-5) and of the econometric results (table 4). The dominance of gasoline use of the standard car segment is due to its higher level of mileage $(+30 \%)$ if compared to that of the mini car or the small car. In other words, despite the increase in vehicles sales of mini cars the standard car class becomes the top gasoline consumer in the projection plotted in figure 5.

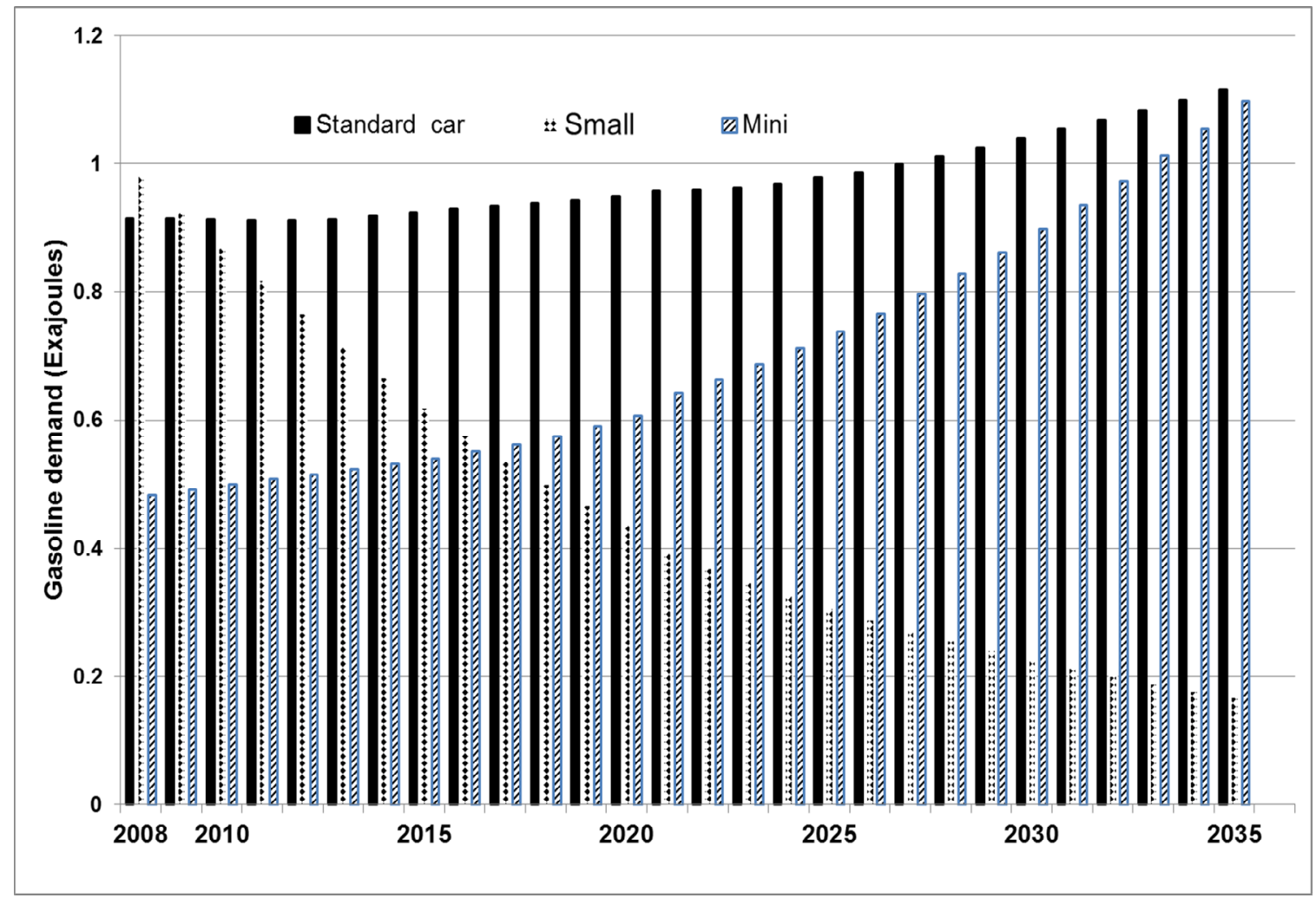

Figure 5. Gasoline demand under decaying fuel economy (DFE) by vehicle size. New cars only (See eq. 3). The forecasts include changes in the vehicle mix to the year 2035. Data is corrected to remove the gap between on-road and test fuel economy (new cars). 
Since the projection exercise includes changes in new car fuel economy (by vehicle class), two cases are generated in the projection: a fuel economy improvement (FEI) case (without decaying fuel economy of cars) and a decaying fuel economy (DFE) case (figure 6). The FEI case applies where historical trends in fuel economy would continue into the future.

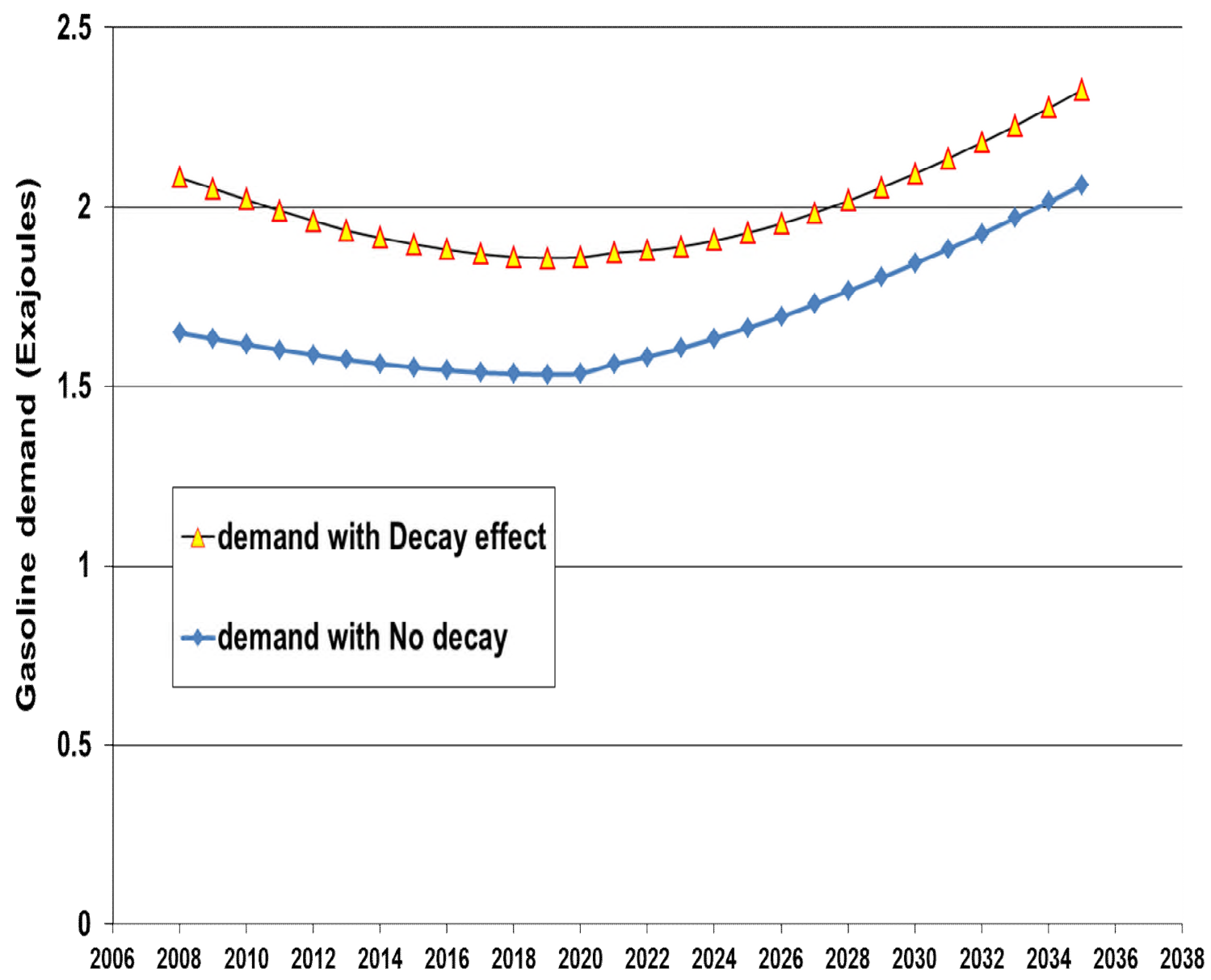

Figure 6. Projections for gasoline demand (with decay effects) to 2035 . Data is corrected to remove the gap between on road and test fuel economy (new cars). The forecasts include changes in vehicle mix to the year 2035.

Under the DFE (decay effect for fuel economy of new cars) we produce several cases for each car class. In the DFE case, the model shows that the effect of including decay effects for fuel economy shifts the demand for gasoline downwards and then upwards by 2035 (Fig. 6). 
In the DFE projection, we assume policy and market failure, or an assumption that new car fuel economy, KM per Litre, (subject to car manufacturer behaviour) will not improve in the projection period as much as expected: Under DFE, the assumption is that vehicle technology degrades overtime.

Figure 5 is a disaggregated picture of Figure 6 which shows a simulation of gasoline demand using the equations 1-5 and the car sales models (Eq. 7). For example, following an improvement in fuel economy of $1 \%$ per year for each vehicle class, the exercise concludes that gasoline demand approaches 1.86 EXJ by 2020 and 2.3 EXJ BY 2035 (Fig. 5 and 6). (Vehicle use is held constant throughout the projection). Figure 5 reveals that the growth in gasoline demand stems from the mini and standard cars classes replacing the growth from the small car class by 2035 .

Furthermore, the model can explain the effects of raising the average fuel economy by class of vehicle (in the FEI case) in $0.17 \mathrm{~km} /$ litre increments up to $16.7 \mathrm{Km} / \mathrm{L}$ (weighted average of 3 vehicles) by 2020 and by 2035. In all projections no rebound effect is assumed (this is defined as the increase in KM-driven given a decrease in the cost per kilometre, in turn, led by declines in gasoline prices (Greening 1995, pp. 394). Vehicle usage is assumed to remain flat and drivers do value (rank) fuel economy highly in their driving decisions.

The projections (2008-2035) for gasoline consumption, by vehicle class, are generated using the stylised facts (Eq. 5, 7) as we next show. The projections raise two issues. First, vehicle prices have a strong effect on the volume of vehicle stock (via sales of these). Second, the projections (Figure 5 and 6) show that it is not feasible to achieve reductions in gasoline consumption providing consumers choose, or buy, more energy efficient vehicles even assuming modest improvements in fuel economy of cars that are sold (Figure 5, 6).

Projections of gasoline demand, resting on those for new car fuel economy to 2035, are further adjusted according to Equations 2 and 3. This can be seen in Figure 6. If the model includes the decay of fuel economy (Eq. 2) two effects emerge: 1) It offsets the fuel saving effect 
(of new car fuel economy in the projection period) and 2) it produces lower gasoline savings for all three vehicles. Decay effects of fuel economy reflect real world conditions of efficiency improvements of new cars.

Figures 5 and 6 reveal levels for gasoline demand to 2035 and the factor of 0.7 is used to correct the gap between test fuel economy (new cars fuel economy) and on road fuel economy. Projections for national gasoline use to 2035 show gasoline savings of $10 \%$ compared to 2008 in the $2008-2020$ period or an increase of $11.5 \%$ by 2035 (Figure 6).

We have introduced a gasoline model that simulates gasoline demand to 2035. The models confirm that savings of gasoline demand will be challenging if the sales of more efficient cars decline while those of standard ones, and less fuel efficient, increase. In our model, sales of small cars fall which, in turn, leads to a decline in their vehicle stock translating into less fuel saved. Although the effect of the stock of small cars outweighs that of the mini car, the model predicts a decline in aggregate gasoline demand to 2035 .

\section{Discussion}

In 2008, vehicle use continues to clog Japanese roads, which increases gasoline demand, leads to high oil dependency and to ever higher $\mathrm{CO}_{2}$ emissions notwithstanding the strong improvements in new car fuel economy of Japanese car fleets and the tax discounts for buyers of small and mini cars. The policy implications are related to the (a) models conclusions and (b) to the analysis that goes beyond the data on car sales and gasoline demand trends.

Understanding how consumers choose fuel efficient cars following cost changes, gasoline price effects and household budget levels, during 1980-2008, is key for building more accurate gasoline demand projections. The econometric evidence for underinvestment in fuel economy is mixed. On the 
one hand consumers underinvest in fuel economy (small car class) since sales are negatively associated to increases in capital costs in the short run. On the other, consumers do buy fuel economy (of mini cars) despite the increase in capital costs in the short run. Buyers of large cars do not buy fuel economy since they are not sensitive to capital costs increases. In contrast to the short run, in the long run consumers do not invest in fuel economy since they are more sensitive to capital costs increases, this is specially so for the small and mini car classes. Large vehicle buyers however, also reveal sensitivity to capital costs in the long run. In summary, consumers do not always underinvest in fuel economy.

In the long run consumers buy fuel economy following an increase in fuel prices and during 19802008. Consumers substitute small for large vehicles and small ones for mini vehicles but this needs further exploration in future work. The model shows that the vehicle mix, on the road and at the point of sales, is as important as the level of fuel economy and the level of vehicle traffic. The projections produced reveal that the vehicle mix is key in any gasoline reduction strategy.

The projection to 2035, for on the road car fleets shows that large and mini cars segments will dominate the car market. The projections confirm that large gasoline savings are attained by the year 2020 but these savings are reversed by 2035 . In the projection to the year 2035, consumers do invest in fuel economy and this is reflected in the increase in sales of mini cars.

The disaggregated model of gasoline demand and car sales leads to five policy implications. First, Japan's goal of decreasing oil dependency of the transport sector is in peril so long as buyers of large cars are unresponsive to gasoline price and capital cost levels in the short run. Second, policy makers should set targets not only fuel economy levels of new cars but target the market share of more energy efficient cars such as the mini and the small cars that we have 
modelled in the paper. The top runner programme, currently used, targets the new car market but not the on-road car fleet. A national congestion charge scheme is also an effective tool to reduce the traffic generated by the large car class.

Third, policy makers should set behavioural campaigns, along with financial education of car buyers, to incentivise further sales of energy efficient vehicles; fourth, policy makers should also consider possible decay effects on fuel economy performance when building projections of gasoline demands. Fifth, to further reduce the high capital cost burden consumers could be given even lower taxes on car ownership specially for buyers of small or mini cars.

We can draw the following conclusions beyond the model and the data. New perspectives that help to explain why consumers underinvest in fuel economy have emerged (Greene, 2010) but this have not been fully incorporated in projections of gasoline demand fully. The evidence on underinvestment in fuel economy, gathered in this paper, is mixed for the case of Japan.

The current model could be extended by incorporating a larger pool of vehicle types, a disaggregation of household incomes, and of vehicle fuel economy levels. Future models should include variables for the vehicle choice behaviour (by car class) which affects driving distance and fuel use. 


\section{Appendix A}

Table 6. list of variables for models, parameters and coefficients employed in the gasoline models

\begin{tabular}{|c|c|c|}
\hline Abbreviation & Variable Name & Units \\
\hline HI & Real household income (GDP/Household) & proportion \\
\hline $\mathrm{H}$ & Number of Households & millions \\
\hline GP & Gasoline price index & Index: $2000=100$ \\
\hline CPI & Consumer price index need line under this box & Index: $2000=100$ \\
\hline ANR & Sales standard vehicle & $1000 \mathrm{car}$ \\
\hline ANS & Sales small vehicle & $1000 \mathrm{car}$ \\
\hline ANM & Sales mini car vehicles & $1000 \mathrm{car}$ \\
\hline CAPCO & Capital cost by vehicle class & Index: $1985=100$ \\
\hline MSR & $\begin{array}{l}\text { Actual Mileage of both standard and small } \\
\text { vehicles; (also miles per vehicle) and average } \\
\text { over both classes }\end{array}$ & $000 \mathrm{Km}$ \\
\hline MM & Actual Mileage of mini vehicles & $\mathrm{Km}$ \\
\hline $\mathrm{RE}$ & Fuel Economy new standard vehicle & $\mathrm{Km} / \mathrm{L}$ \\
\hline RS & Fuel Economy new small vehicle & $\mathrm{Km} / \mathrm{L}$ \\
\hline RM & Fuel Economy new mini vehicle & $\mathrm{Km} / \mathrm{L}$ \\
\hline G & Estimated gasoline demand of kth vehicle & EXAJOULES \\
\hline$S$ & Surviving vehicle stock & 1000's vehicle \\
\hline$\gamma$ & Survival rate of Vehicles (by Age of vehicle) & Rate \\
\hline $\mathrm{E}$ & New Vehicle Fuel Economy ( vehicle class) & $\mathrm{Km} / \mathrm{L}$ \\
\hline TAEFF & $\begin{array}{l}\text { New Vehicle Fuel Economy (all vehicles, } \\
\text { average) }\end{array}$ & $\mathrm{Km} / \mathrm{L}$ \\
\hline B & Kilometers per vehicle & $1000 \mathrm{~km} / \mathrm{car}$ \\
\hline 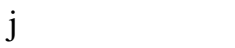 & Index for vehicle age & $1-18$ years \\
\hline $\mathrm{k}$ & Index of vehicle types: standard, small and mini & $1-3$ \\
\hline $\mathrm{i}-1$ & Previous year & \\
\hline
\end{tabular}




\section{Acknowledgements:}

This work is funded by the University of Oxford (under the project "the Institute of Carbon and Energy Reduction in Transport, funded by the Oxford Martin School, University of Oxford). The funding source has had no involvement in the study design, the collection, analysis and interpretation of data; in the writing of the report; and in the decision to submit the paper for publication. This draft benefits from comments that were kindly offered in 2010 by Dr. L. Schipper (Precourt Energy efficiency Center- Stanford University) on an earlier draft. Akira Yanagisawa at the International energy Agency/ Institute of Energy Economics Japan provided the recent Handbook of Energy \& Economics Statistics in Japan. 


\section{References}

Archibald, R, Guillingham R.:1980 Analysis of the short run consumer demand for gasoline using household survey data. Review of Economics.\& Statistics, 62, (4) 622-628

Baltagi, B, Griffin J. 1983. Gasoline demand in the OECD: an application of pooling and testing procedures. European Economic. Review. 22, 117-37. (1983)

Barla, P., Lamande, B., Miranda Moreno, L. B., Boucher, N. 2009. Travelled distance, stock and fuel efficiency private vehicles in Canada: price elasticities and the rebound effect. Transportation, 36, 386-402.

Berndt, E, Botero G.1983 Energy demand in transportation sector of Mexico. J. Development Econonmics (17), 219-238 (1983)

Blomqvist, A G., Haessel W. 1978. Small cars, large cars, and the price of gasoline. Canadian Journal. of Economics. 11 (august): 470-489.

Bonilla, D. 2006. The demand for gasoline of passenger vehicles in Japan to 2010: a vehicle stock and vehicle efficiency approach. In: The International Association of Energy Economics (IAEE), $29^{\text {th }}$ International Conference, Securing Energy in Insecure Times, 7-10 June, 2006. Potsdam, Germany. (2006)

Bonilla, D., Foxon, T. 2009. Demand for New Car Fuel Economy in the UK, 1970-2005. Journal. Of Transport . Economics \& Policy 43 (1): 55-83

Busse M. R., Knittel C. R.., Zettelmeyer, F. 2010. Pain at the pump: on new and used automobile markets. Working Paper, 15590. National Bureau of Economic Research, Cambridge, MA.

NBER working paper series. Available at: http://www.nber.org/papers/w15990.

Dahl, C.1995 Demand for transportation fuels: a survey of demand elasticities and their components. The Journal. Energy Literature, 2, (I): 3-27

Davis, S., Diegel, S. 2007. Transportation energy data book: Edition 26. Oak Ridge National Laboratory, Center for Transportation Analysis. Oakridge TN

Energy Conservation Center of Japan (ECCJ) 2005. What is the top runner programme?. Agency of Natural

Resources and Energy, Japan, 2005. See also: www.enecho.meti.go.jp

Espey, M. 1998. Gasoline demand revisited: an international meta-analysis of elasticities. Energy Economics.

20, 273-295

Fischer, C., Harrington, W., Parry, I.W.H. 2007. Should Automobile Fuel Economy Standards be Tightened ?

The Energy Journal. 28, 4, 1-29 (2007)

Gately, D. 1990. The U.S. demand for highway travel and motor fuel. The Energy J. 3 (11): 59-72

Graham, DJ., Glaister S. 2002. The demand for automobile fuel. J. Transp. Econ. Policy 36, Part 1, 1-26

Greene, DL. 1990. CAFE OR PRICE: An Analysis of the effects of federal fuel economy regulations and gasoline price on new car mpg, 1978-89. The Energy Journal. 11, (3): 37-58. (1990)

Greene, D. (2010) Why the new market for new passenger cars generally undervalues fuel economy. JTRC Discussion paper 2010-7.

Greening, LD, Greene D, Difiglio C. 2000.Energy Efficiency and Consumption- the rebound effect- a survey. Energy Policy 28, 389-401

Greenspan, A., Cohen, D. 1996. Motor vehicle stocks, scrappage, and sales. 1-33, 
Federal Reserve. See also www.federalreserve.gov/pubs/feds/1996/199640pap.pdf

Hughes, J.E., Knittel, C.R. Sperling (2009) Evidence of a shift in the short run price elasticity of gasoline demand. The Energy Journal, 29 (1), 93-114.

ICCT (International Council on Clean Transportation) 2007. Passenger Vehicle greenhouse gas and fuel economy standards: A global update. Report, 1-36. Washington DC

IEA (2007) Energy Balances of OECD Countries. Paris

IEA (2008) Japan 2008 Review, Energy policies of IEA countries. Paris, France, 1-220

Japan Institute of Energy Economics (2010.) Handbook of Energy Economics and Statistics, EDMC. Tokyo:

The Energy Conservation Center.

Japan Institute of Energy Economics. 2006. Japan Long Term Energy outlook: A Projection up to 2030 under

Environmental Constraints and Changing Energy Markets. EDMC, 2006 IEEJ, K. Ito., Y., Morita,

Yanagisawa, A., Suehiro, S. June. In 394th Forum on Research Works on April 26. See also:

ttp://eneken.ieej.or.jp/en/whatsnew/394.htm

Japan Automobile Manufacturers Association (JAMA) 2006. "2006 the Motor Industry of Japan” See also:

www.JAMA-english.jp/index.html

Japan Automobile Manufacturers Association (JAMA) 2003.Jidousha Nennkann Handbook. 2002-2003

Edition), Nikkan Jidousha Shinbun-sha, Nippon Jidousha Kaigisho, ISBN:4901830082

Japan Automobile Manufacturers Association (JAMA). 2003. Automobile (Jidousha ) Guidebok. 2003.

Japan Statistical Bureau 2010. Bukka Shisuu Nennppou (Consumer Price Index (CPI)). Available at:

http://www.stat.go.jp/data/cpil

Johansson, O., Schipper L. 1997. Separate estimations of vehicle stock mean fuel intensity and mean annual

driving distance. J. Transp. Econ. Policy; 31 (3): 277-292

Kayser, A. 2000.Gasoline demand and car choice: estimating gasoline demand using household information.

Energy Economics. 22 (3): 331-348

Kazimi, C. 1997 Evaluating the environmental impact of alternative fuel vehicles. Journal of Environmental.

Economics. Management. 33, 163-185

Lave, C.A, Train, K. A. 1979. A disaggregate Model of Auto type choice. Transportation Res. 13A: 1-9

Mannering, F, Mahmassani, H. 1985. Consumer valuation of foreign and domestic vehicle attributes:

Econometric analysis and implications for Auto demand. Transportation Research. A 19A, 243-251

McCarthy, P. S. 1996. Market Price and income elasticities of new vehicle demands. The Review of Econ.

Statistics 78, (3), 543-547

Ministry of Land Infrastructure and Transport. 2008. Survey on Transport of Energy. Information and research department, Policy bureau. See also: http://www.mlit.go.jp/english/

National Institute of Population and Social Security Research. 2010. Population projections. See also: www.ipss.go.jp/index-e.html

Nicol, C. J. 2003. Elasticities of demand in Canada and the United states. Energy Economics, 25, (2): 201-214

Oladosu, G. 2003.An almost ideal demand system of household vehicle fuel expenditure allocation in the United

States. The Energy Journal. 24, (1) 1-21 
Sakaguchi, T. 2000. Influence for fuel efficient motor vehicles on gasoline demand for individual user owned passenger cars. Institute of Energy economics, Japan.See also: ttp://eneken.ieej.or.jp/en/

Sano, M. 2008. Fuel efficiency of passenger cars in Japan. Paper presented at the new energy indicator for transport: the way forward. 28-29 ${ }^{\text {th, }}$ IEA, Paris.

Santini, D. 1994.Transportation technology transitions and macroeconomic growth-contemporary evidence. Center for Transportation Research, Argonne National Laboratory, U.S. ANL/ES/CP-84/328. CONF9411164-1. In International Workshop on the Motor Vehicle and the Global Environment Problem,Tokyo 1994. p.1-31

Schipper, L. 2007. Automobile fuel economy and CO2 Emissions in industrialised countries: Troubling trends through 2005-06. Embarq, The World Resources Institute Center for sustainable transport. Washington DC, U.S.

Schmalensee, R., Stoker, T.M. 1999. Household gasoline demand in the United States. Econometrica; 67 (3): 645-662

Small, K. A., Van Dender, K. 2006. Fuel Efficiency and Motor Vehicle Travel: the Declining Rebound effect. UCI Department of Economics. Working Paper 050603.

Thomas,R. L. (1997) Modern Econometrics: an introduction. Prentice Hall, London. pp 1-531.

Figure 1. Fuel consumption: passenger cars. Source: author using data of IEEJ (2010) and MLIT 2008)

Figure 2. Vehicle sales in Japan (by class). Source: IEEJ, 2010

Figure 3. New car fuel economy (by class). Source: Japan Automobile Manufacturers Association, 1985-2003 (10.15 drive cycle test. Source :This author for years 20022020.

Figure 4. Projections for vehicle sales new cars: small car loses market share.

Figure 5. Gasoline demand under decaying fuel economy (DFE). ). (by vehicle size assuming decay effects for fuel economy of new cars) (see Eq. 3). Data is corrected to remove the gap between on road and test fuel economy (new cars)

Figure 6. Projections for gasoline demand Data is corrected to remove the gap between on road and test fuel economy (new cars). 
